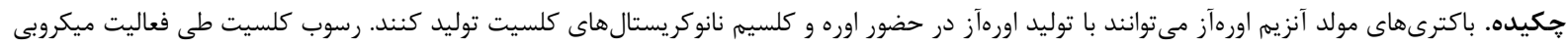

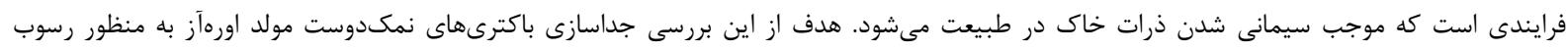

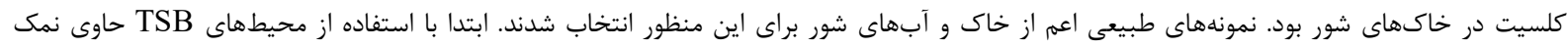

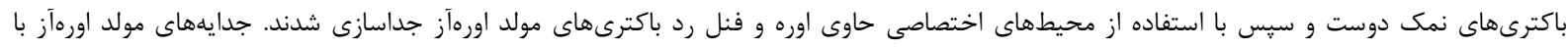

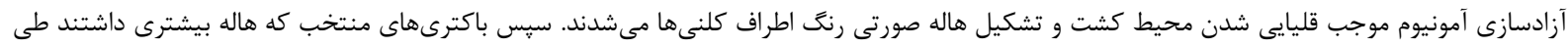

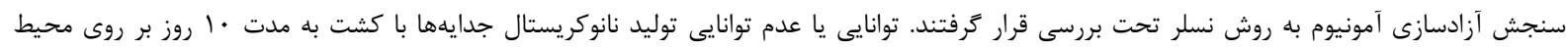

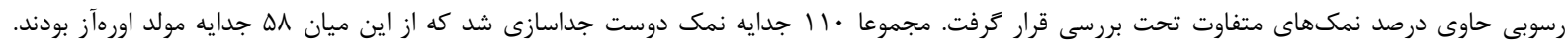

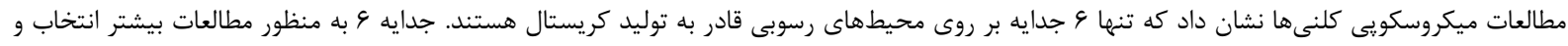

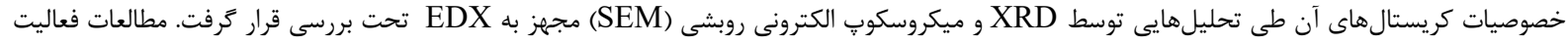

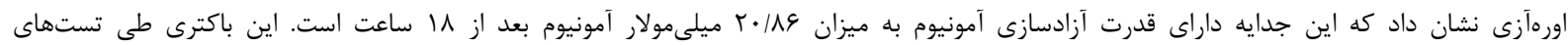

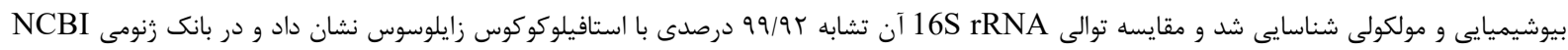

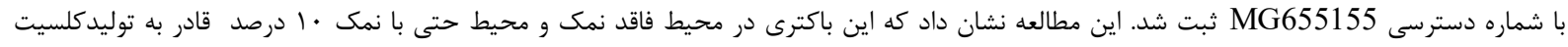

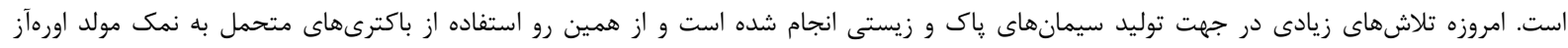
كانديداهاى مناسبى به منظور سيمان سازى زيستى در محيطهاى ناى شور است. وازههاى كليدى. يراش اشعه ايكس، سيمان زيستى، كلسيت، نانوكريستال، ميكروسكوب الكترونى روبشى

\title{
The isolation of halophilic urease-producing bacteria and the study of their nano-crystal production
}

\author{
Maryam Haddadi \& Gholam Reza Ghezelbash \\ Department of Biology, Faculty of Science, Shahid Chamran University of Ahvaz, Ahvaz, Iran \\ Correspondent author: Gholam Reza Ghezelbash,rghezelbash@scu.ac.ir
}

\begin{abstract}
Urease-producing bacteria can precipitate calcite nano-crystals by producing urease in the presence of urea and calcium. Calcite precipitation resulting from microbial activity is a process which causes cementation of soil particles in nature. The purpose of this study was to isolate urease-producing halophilic bacteria in order to precipitate calcite in saline soil. Natural samples, including soil and saline waters, were selected for this purpose. At First, halophilic bacteria were isolated by salt-containing TSB medium. Then, a selective medium containing phenol red and urea facilitated the isolation of urease-producing bacteria. Hydrolysis of urea by urease causes alkalization of the medium and the formation of pink halo around colonies. Finally, the best isolate was selected for further study by measuring the release of ammonium by the Nessler method. The ability or inability of isolates to produce calcite was investigated by culturing the isolates on sedimentary medium with different salt concentrations for 10 days. In total, 110 halophilic isolates were isolated, among which 58 isolates had the ability of urease production. The microscopic studies of colonies showed that only 6 isolates were able to produce crystals on precipitation medium. Isolate 6 was selected for further study and then analyzed by X-ray diffraction crystals on precipitation medium. Isolate 6 was selected for further study and then analyzed by X-ray diffraction (XRD)
\end{abstract}


and scanning electron microscope (SEM) equipped with an energy dispersive X-ray (EDX) detector. Studies of urease activity showed that this strain released $20.86 \mathrm{mM}$ ammonium after 18 hours. This bacterium was identified by biochemical and molecular analyses and the comparison of its 16S rRNA gene sequence showed $99.92 \%$ similarity with the similar gene sequence in Staphylococcus xylosus and then this sequence was submitted in NCBI database with the accession number MG655155. This isolate was able to produce calcite in free salt medium, with salinity up to $10 \%$. Nowadays, many efforts have been made to produce environmental-friendly cements, and therefore, the use of ureaseproducing halophilic bacteria is an appropriate candidate for bio-cementing in saline environments.

Keywords. biocement, calcite, nanocrystal, scanning electron microscope, X-ray diffraction

كربنات كلسيم مىشوند. جدا از نقش اين آنزيم در توليد اين

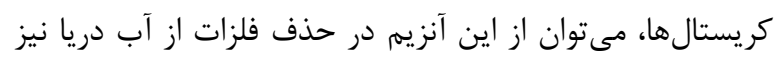
استفاده كرد (Arias et al., 2015). باكترىهاى نمك دوست باكترىهايى هستند كه براى رشد به

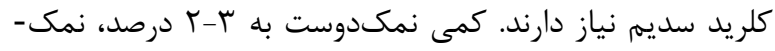

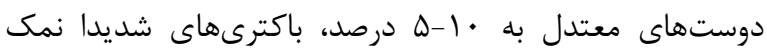

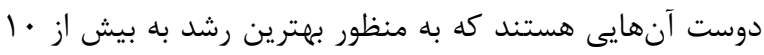
درصد كلريد سديم نياز دارند. باكترىهاى غير نمكدوست نيز

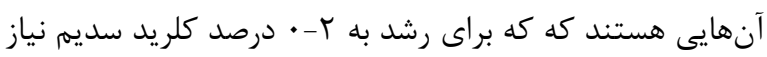

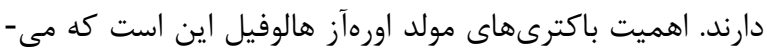
توان از اين باكترىها و آنزيمهاى آنها در محيطهاى طبيعى مونى حاوى نمك به هر منظور بيوتكنولوزيكى از جمله سيمانى كردن

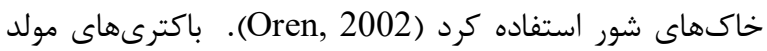
اورهآز كه براى سيمانسازى زيستى خاكهاى شور به كار مىروند بايد در محيط زئوتكنيكى با غلظت بالاى نمك فعلى فعال باشند.

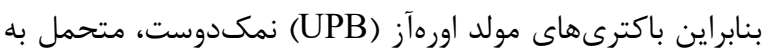
نمك و قليادوست بايستى انتخاب ارجح به منظور سيمانى شدن

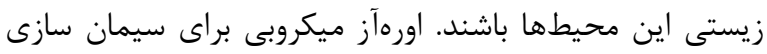

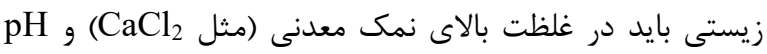

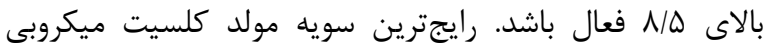

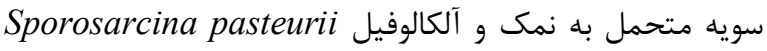
است كه در مطالعات زيادى از MICP استفاده شده است

.(Stabnikov et al., 2013)

باكترىها به عنوان جايعاههاى هستهساز در رسوب كربنات

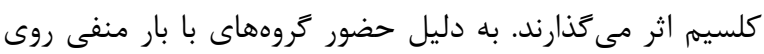

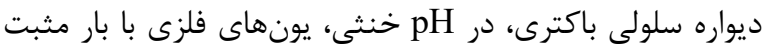

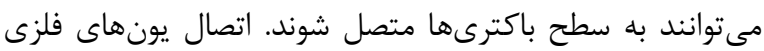

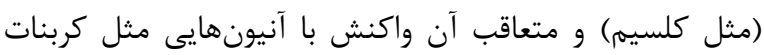
انجام شده و نمك نامحلول كلسيم كربنات به وجود مي آيد ( De مئس

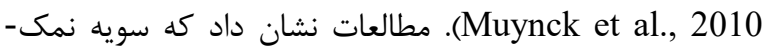
دوست معتدل Deleya halophila جداسازى شده از سواحل مديترانه علاوه بر ويزگى هاى رشدى و نيازهاى نمكى داراى توانايى بسيار خوبى در رسوب كلسيت است ( Rivadeneyra et
آنزيمها بالقوهترين بيوكاتاليستها براى بسيارى از واكنشها

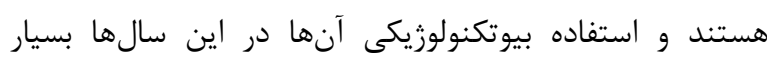

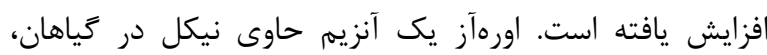

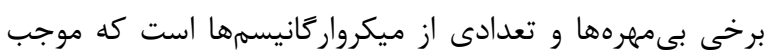

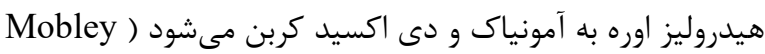

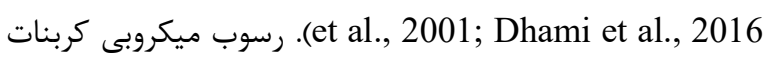
كلسيم (MICP) پپيدهاى است كه بر اساس فعاليت اورهآزى

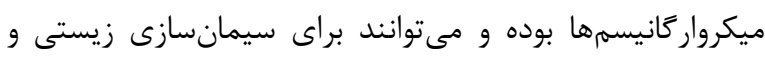
محكمسازى خاى در مهندسى زئوتكنيك استفاده شوند ماند

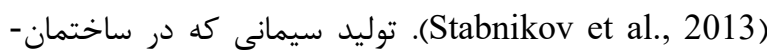
سازى و مقاومسازى بناهاى ساختمانى و همينطور در مهندسى لولى سيدي

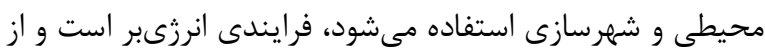
نظر زيست محيطى يك فرايند نامطلوب محسوب مى شىود. توليد جهانى سيمان جدا از نياز به ه درصد مصرف انرزى بله علاوه

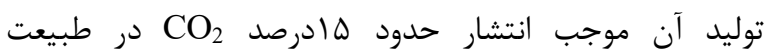
مىشود. از همين روست كه امروزه تلاشهاى زيادى در در جهت توليد سيمانهاى پاك و زيستى انجام شده است. توليد نانو كلسيت ميكروبى طى فعاليت اورهآزى باكترىهاى مولد اورهآز يكى از اين سيمان سازىهاى زيستى است. توليدكريستال

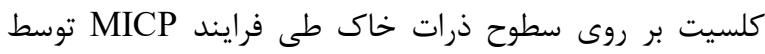
باكترىهاى مولد اورهآز در حضور اوره و يونهاى كلسيم موجب

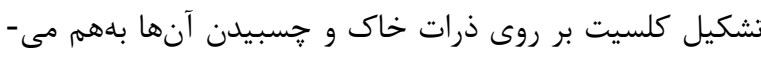
شود (Stabnikov et al., 2013; Arias et al., 2015). كريستالهاى مختلف كربنات كلسيم مانند كلسيت و دولوميت در طبيعت وجود دارند كه باكترىها به عنوان عواملى مههم براى همائينات توليد و رسوب اين مواد معدنى مطرح هستند. معروفترين آن

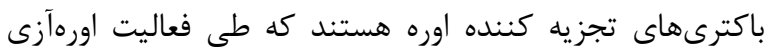
خود اوره را به دى اكسيد كربن و آمونياك هيدروليز مي كنند. آمونياى با آب واكنش داده و موجب توليد دور آمونيوم و يون هيدروكسيد مىشوند. يونهاى هيدروكسيد با دى اكسيد كربن

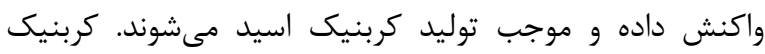
اسيد حاضر با كلسيم واكنش داده و ورجب موجب توليد كريستالهاى 
فوق توسط ميكروسكوب نورى (×• Chahal et ( بررسى شدند .al., 2011 سنجش توانايى تجزيه اوره به منظور بررسى رشد و آزادسازى آمونيوم، هر جدايه به به صورت

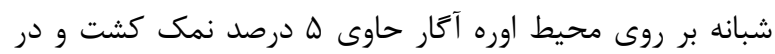

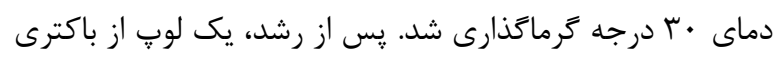

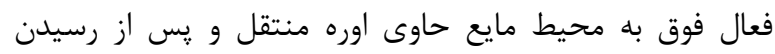

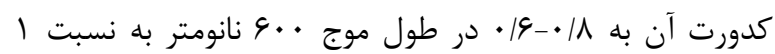

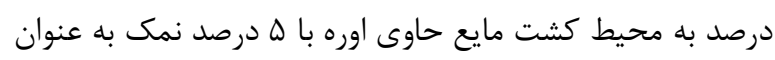

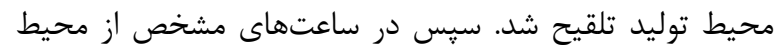

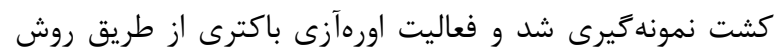

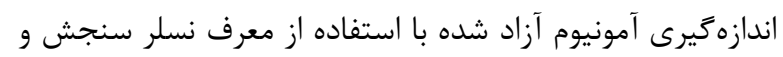

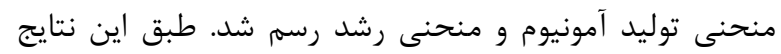

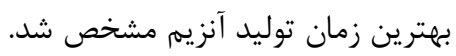

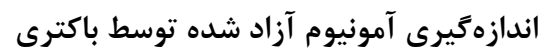

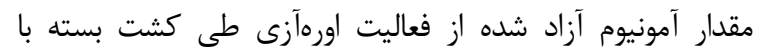

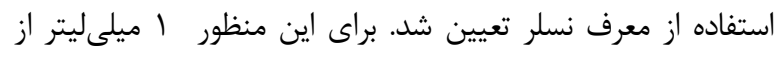

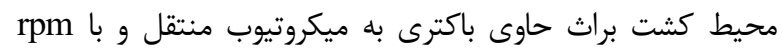

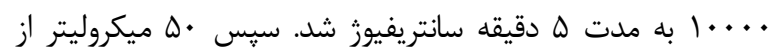

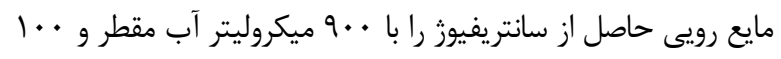

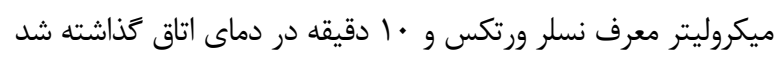

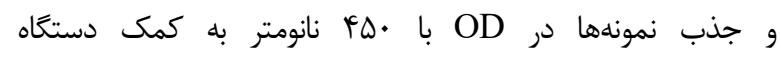

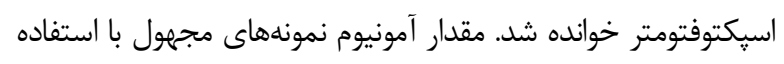
از منحنى استاندارد رسم شده با سولفات آمونيوم مشخص شد شد.

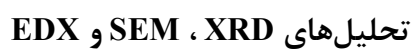
كلنىهايى كه داراى ذرات رسوب يافته كريستال در مطالعه

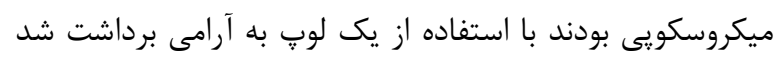

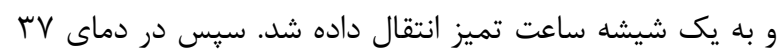
درجه سانتى

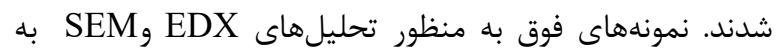

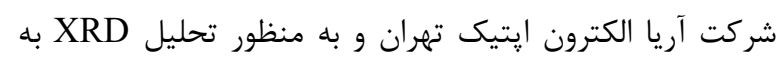

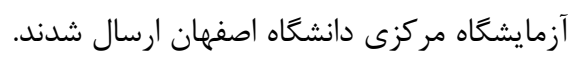
شناسايى باكترى إنئاه مركرى جدايه مولد نانوكلسيت با استفاده از تستهاى موفولوزى، بيوشيميايى (Brenner et al., 2005) و مولكولى شناسايى شد. جهت آناليز مولكولى، استخراج زنوم با روش دستى جوشاندن انجام

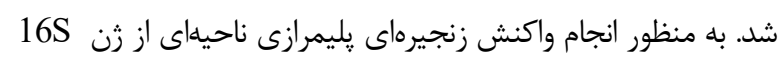
از يرايمرهاى عمومى rRNA

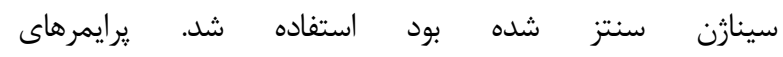
رفت 'AGAGTTGATYMTGGCTCAG-3'

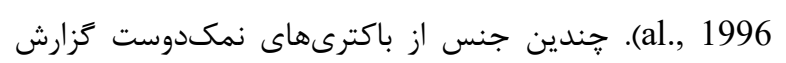

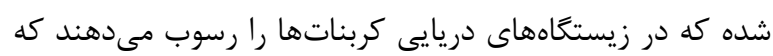

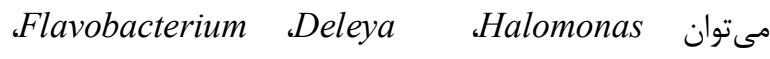
Actinobacteria توان رشد در طيف وسيعى از غلظتهاى اسمزى را دارند كه آن-

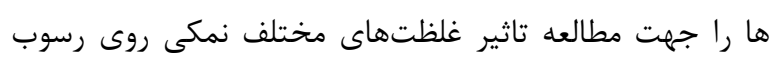

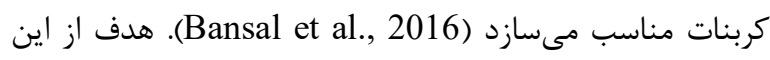

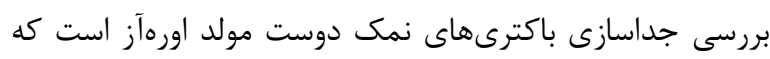
با تحمل در شرايط نامساعد محيطى قادر به توليد كلسيت و و متعاقبا سيمانى شدن اين محيطها هستند.

\section{مواد و روشها ماكيا جداسازى باكترىهاى نمكدوست}

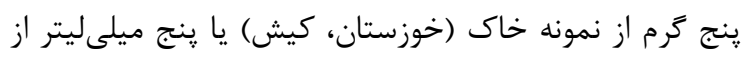

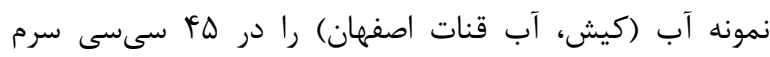

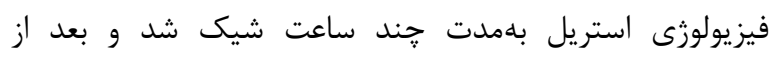

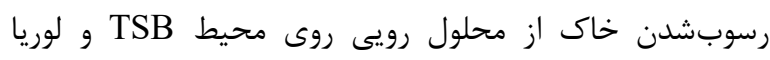

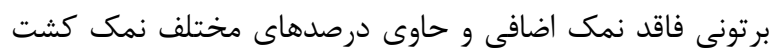

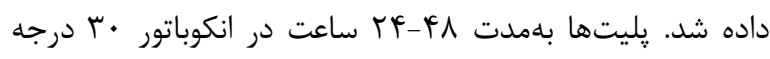

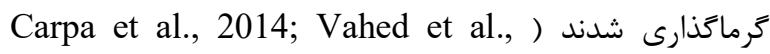
(2011 جداسازى باكترىهاى مولد اورهآز

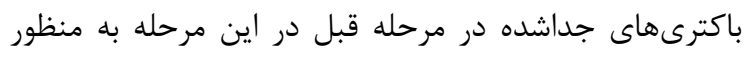

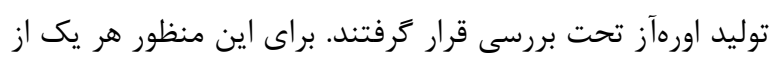

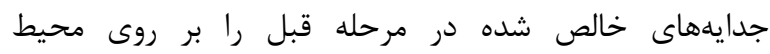

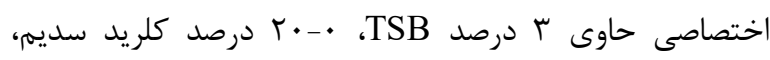

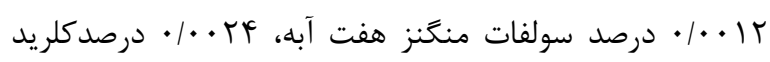

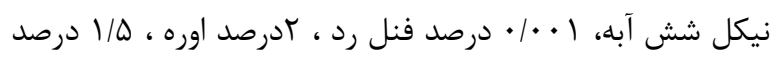

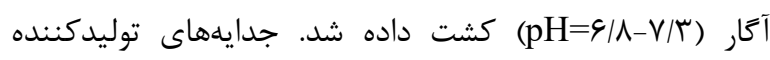

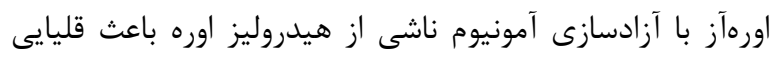

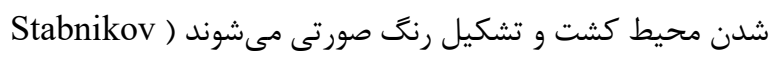
.(et al., 2013

\section{جداسازى باكترىهاى مولد كلسيت}

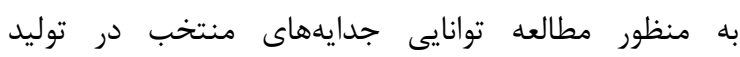

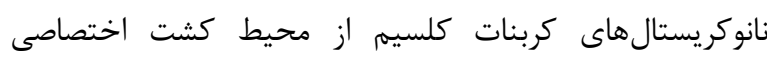

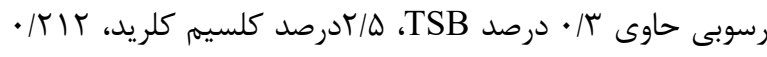

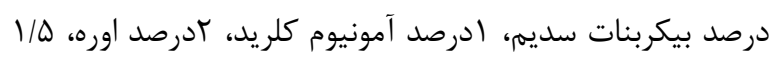

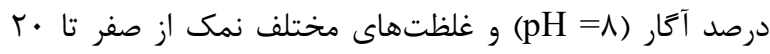

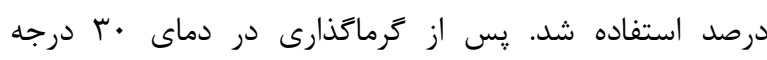
سانتى 
كريستالها در محيط رسوبى فاقد نمك اضافى و همينطور محيط

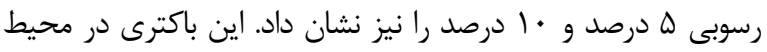

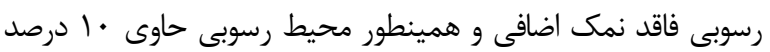

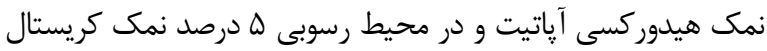

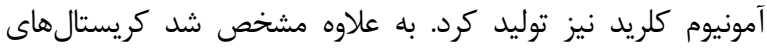

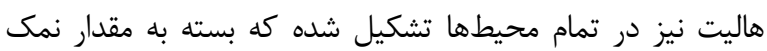
محيط اين مقادير متفاوت بودند.

\section{تصاوير SEM و تحليل EDX}

شكل (و) تصوير ميكروسكوب الكترونى روبشى كريستالهاى

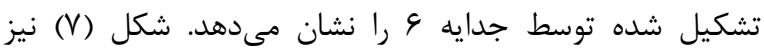
تحليل EDX همان نمونه را با نمايش عناصر تشكيل دهنده

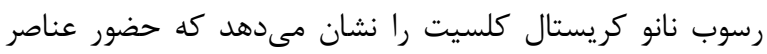

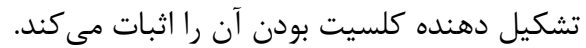

شناسايى باكترى

نتايج مربوط به تستهاى بيوشيمايى جدايه 9 در جدول (1)

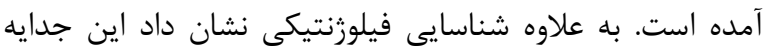

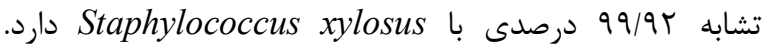
توالى به دست آمده اين باكترى در سامانه بين المللى NCBI با باليه

$$
\text { شماره دسترسى MG655155 به ثبت رسيد. }
$$

بحث

در اين بررسى از ميان و جدايه منتخب كه از منابع طبيعى آب و

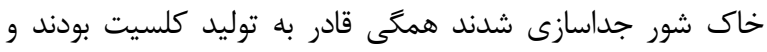
جدايه S. xylosus مورد مطالعه بيشتر قرار گرفت. اين جدايه در محيط رسوبى له درصد و • ا درصد نمك و هم فاقد نمك كلسيت توليد كرد. مطالعات نشان دادند كه رسوب كلسيم كربنات با افزايش غلظت نمكى در Exiguobacterium mexicanum كاهش مى

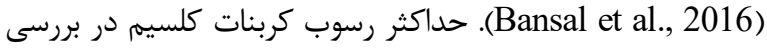
نامبرده در غلظت نمكى / / مشاهده شد اما بيشترين رشد را در غلظت نمك ل V/D و • ا درصد نشان داد. رسوب كربنات كلسيم عمدتا در فشار نمكى · •ادرصد

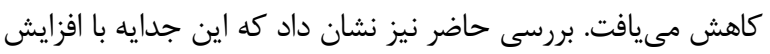

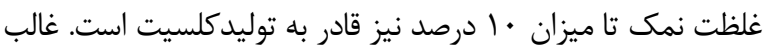
مطالعات انجام شده بر روى نانوكريستالهاى كلسيت طى تحليل - نمان

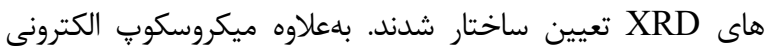
روبشى مجهز به EDX بهترين ابزار براى تعيين مورفولوزى ذرات و ماهيت ذرات نانوكريستال است. مطالعه ذرات كلسيت بر روى رئي باكترى Exiguobacterium mexicanum توسط دميت دمات كه اندازه كريستال هاى تشكيل شده بين ••ه-· ميكرومتر بوده اما واتريت و آراتونيت نيز وجود داشت (Bansal et al., 2016).
TAAGGAGGTGATCCAGCC-3' طول تقريبى . •اص جفت باز شدند. واكنش زنجيرهاى يليمراز در

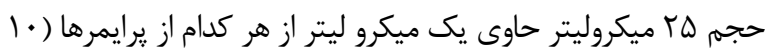

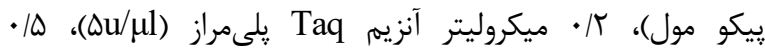

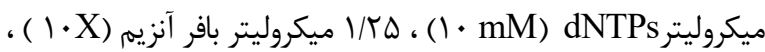

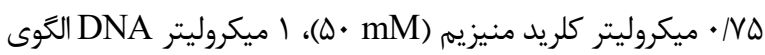

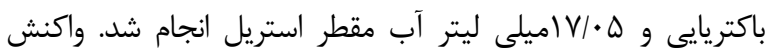
زنجيرهاى يليمراز در دستخاه ترموسايكلر Bio-Rad آلمان با شرايط

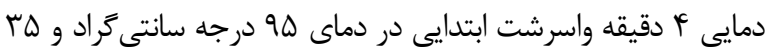

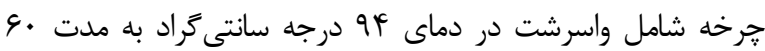

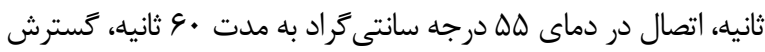

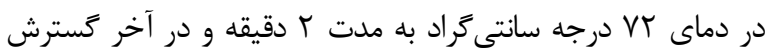
نهايى در دماى VT درجه سانتى

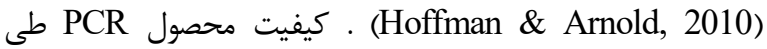
الكتروفورز بر روى زل ا درصد آكارز مشخص و سيس به شركت زيست فناوران رنا (اصفهان) ارسال شد تا توالى آن مشخص رون شود. توالى به دست آمده در سامانه بينالمللى NCBI با توالىهاى موجود

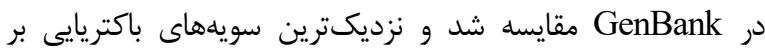
اساس توالىهاى 16S rRNA تعيين و سيس ثبت شد. نُّند

\section{نتنايج جداسازى باكترىهاى نمك دوست مولد كلسيت} از كل • 11 جدايه نمك دوست جداسازى شده، ه ه جدايه جداسازى شده داراى فعاليت اورهآزى بودند كه از ميان اين هـه جدايه، 9 جدايه بر روى محيط اختصاصى حاوى اوره و فنل رد هاله بهترى داشتهاند و به عنوان جدايههاى منتخب استفاده شديط شدند. جدايه \& كه از آب قنات در اصفهان جداسازى شده بود به دليل توليد كلسيت در غلظتهاى بالاى نمك به منظور مطالعات بيشتر

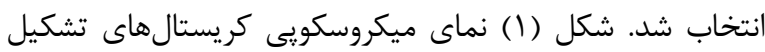
شده توسط جدايه 9 بر روى محيط رسوبى را نشان مى دهد. منحنى رشد و توليد آمونيوم

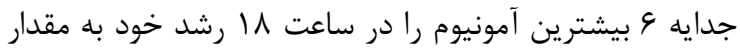

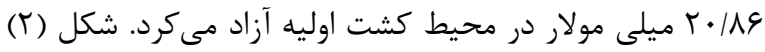
منحنى رشد و آزادسازى آمونيوم را در اين جدايه نشان مي دهدئ. تحليلهاى تصاوير (Y)، (Y) و (ه) نتايج حاصل از XRD كلنى هاى خشك شده جدايه 9 در محيط رسوبى با غلظتهاى مختلف نمك را نشان مى -

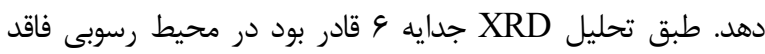
نمك اضافى و همينطور محيط رسوبى حاوى له درصد و • • درصد نمك نانو كريستال كلسيت توليد كند. مطالعات XRD به علاوه ديخر 


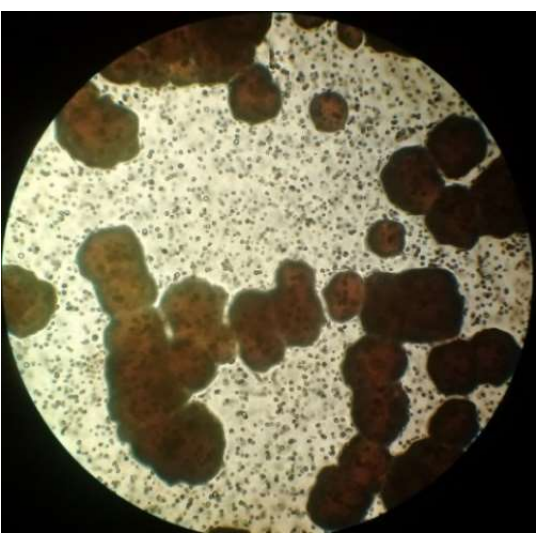

$$
\text { شكل ا- كريستالهاى توليد شده در خارج و داخل كلنىهاى جدايه } 9 \text { بر روى محيط رسوبى با بزر گنمايى ×• }
$$

Fig. 1. Crystals produced outside and inside colonies by isolate 6 streaked on precipitating medium at $40 \times$ magnifications.

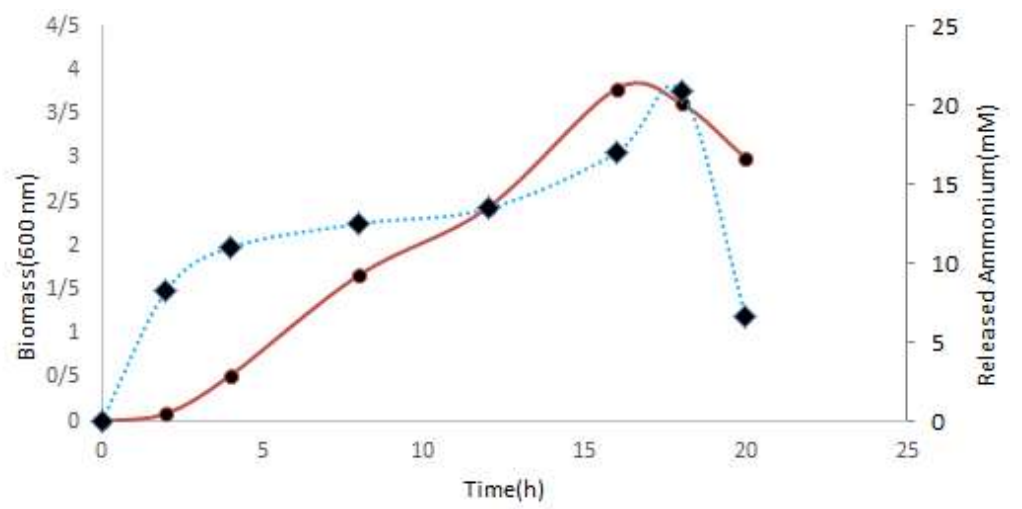

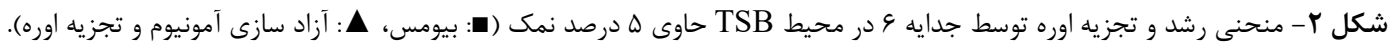

Fig. 2. Growth curve and urea degradation rate for isolate 6 in TSB medium containing 5 \% $\mathrm{NaCl}$.

(घ: Biomass, $\boldsymbol{\Delta}$ : Urea degradation rate)

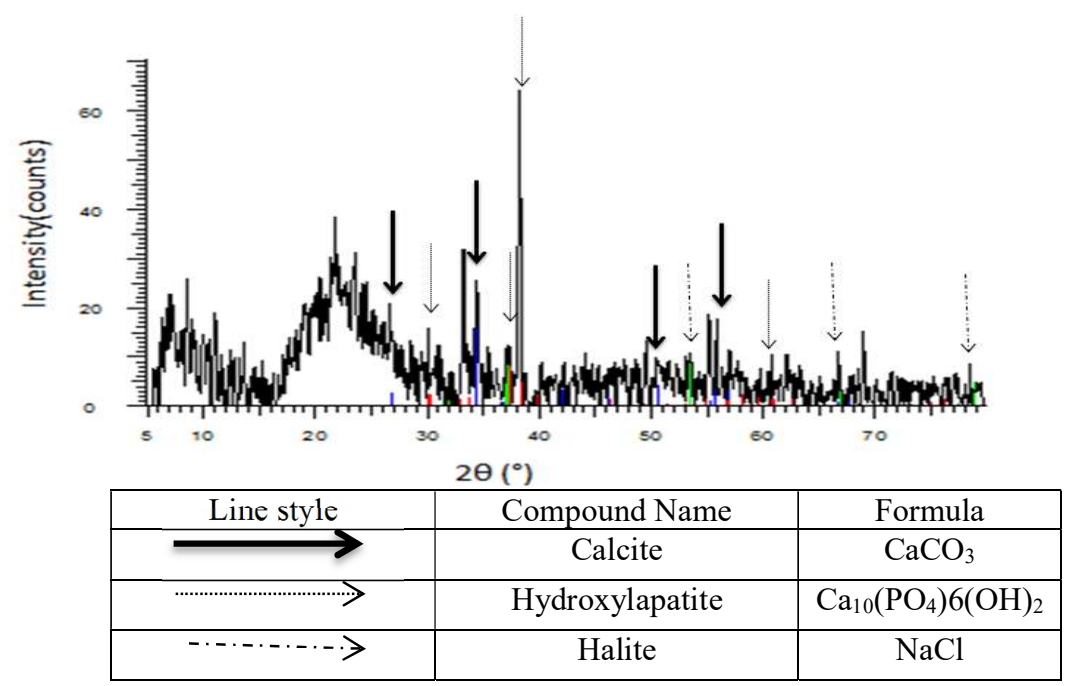

$$
\text { شكل r- الكَوى يراكنش ايكس رسوب ايجاد شده از جدايه } 9 \text { بر روى محيط رسوبى (فاقد نمك اضافى). }
$$

Fig. 3. X-ray diffraction pattern of precipitates collected from isolate 6 were cultured on precipitated medium (without additional salt). 


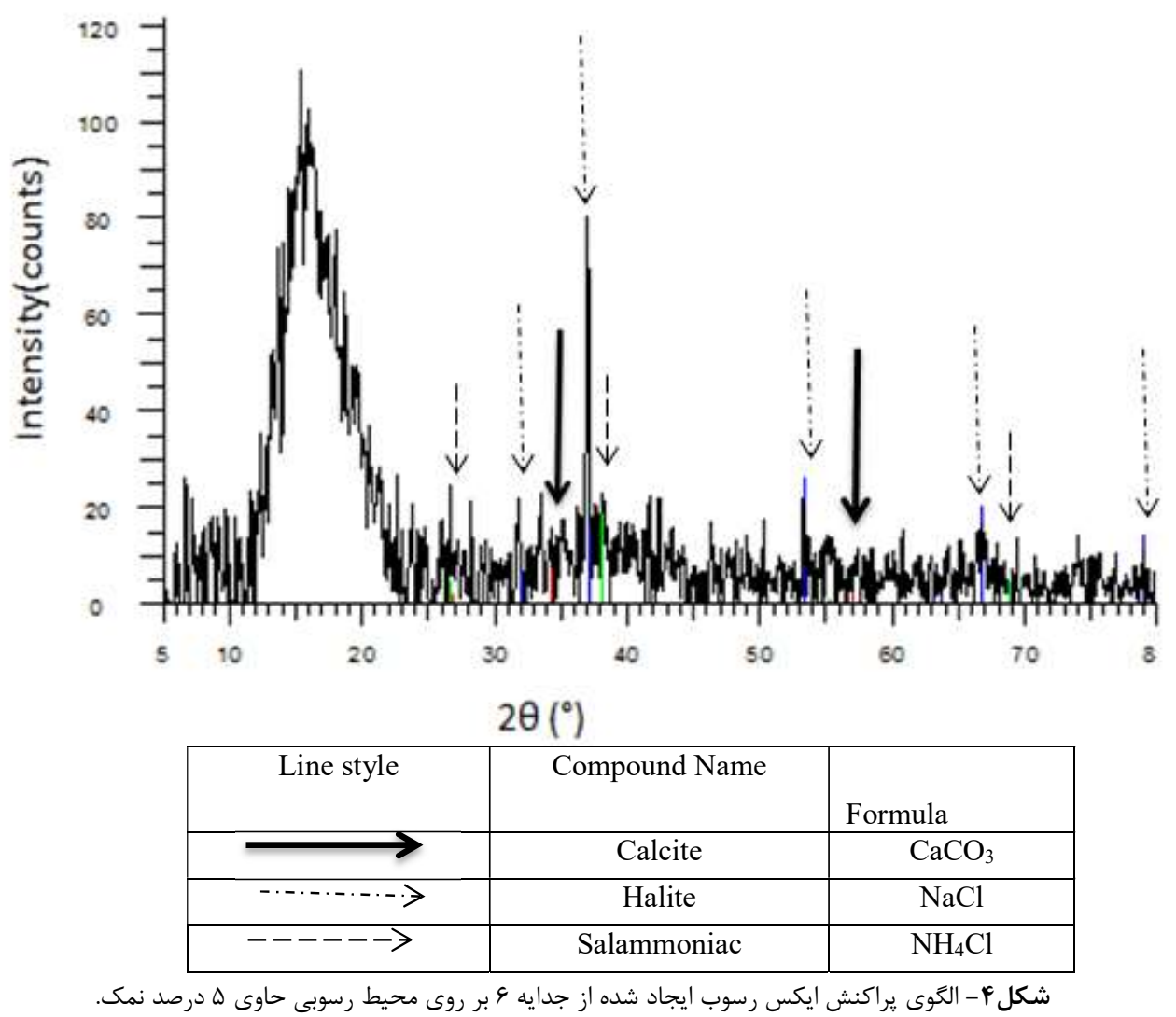

Fig. 4. X-ray diffraction pattern of precipitates collected from isolate 6 cultured on precipitated medium containing 5 \% $\mathrm{NaCl}$.

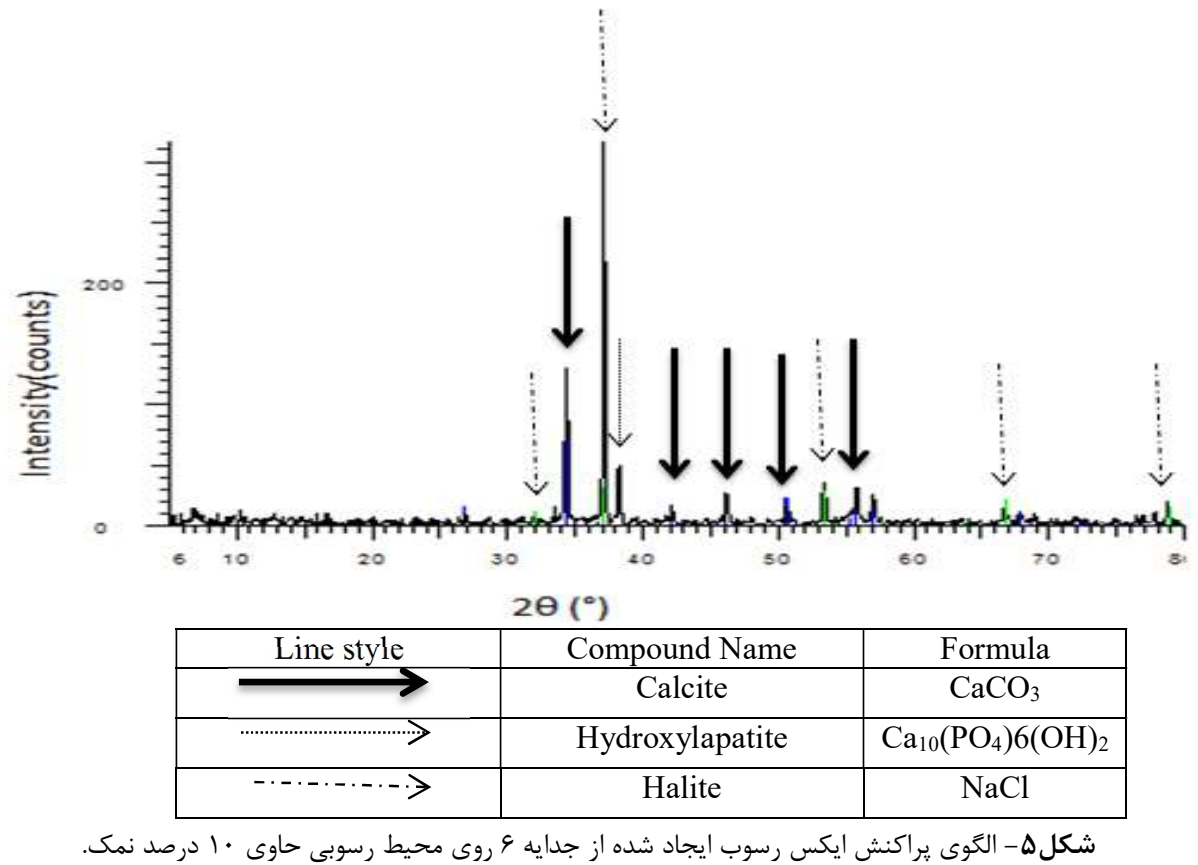

Fig. 5. X-ray diffraction pattern of precipitates collected from isolate 6 cultured on precipitated medium containing 10 $\% \mathrm{NaCl}$. 


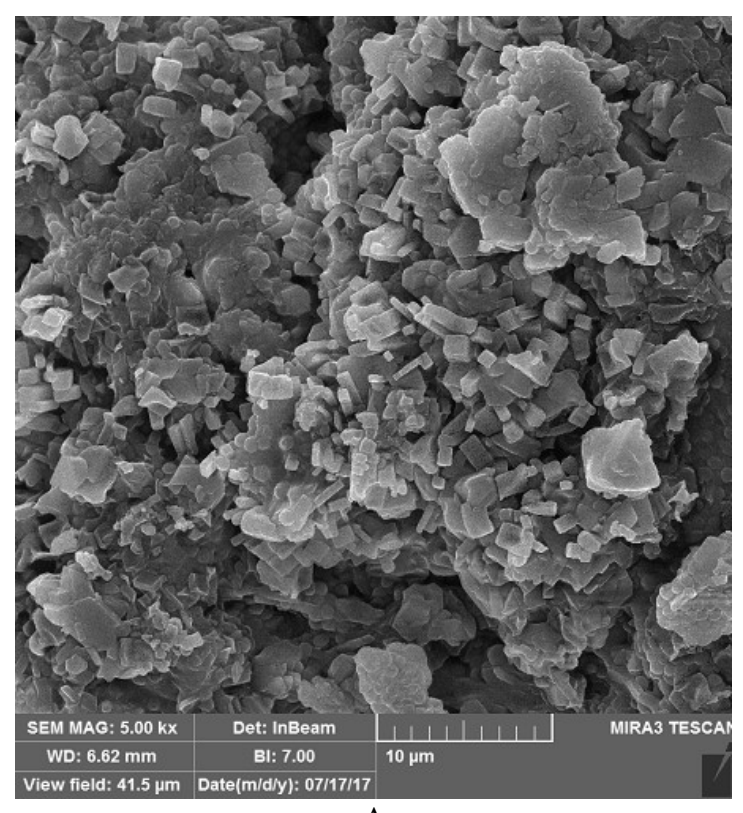

A

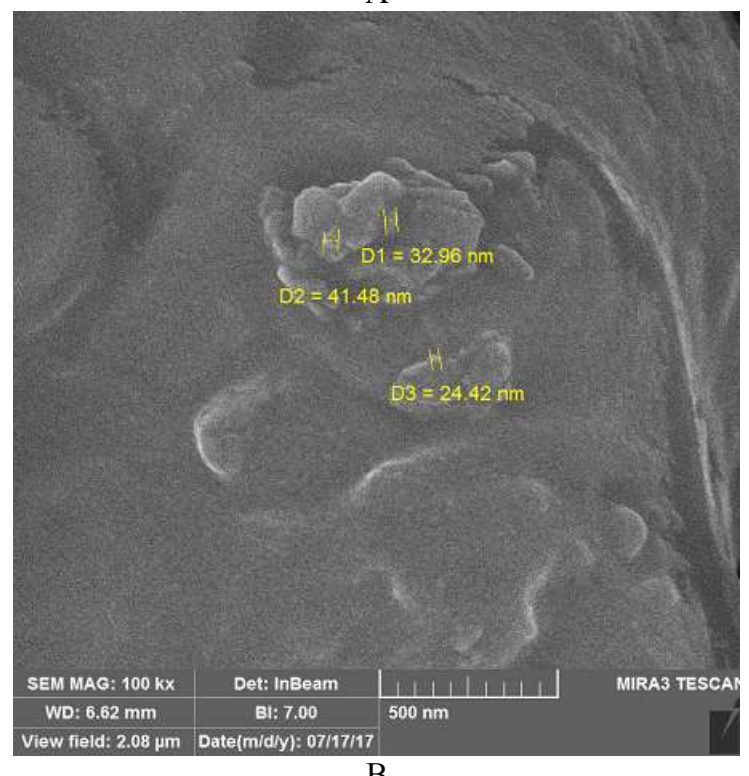

B

شكل 9- تصاوير SEM از تجمعات كريستالها توليد شده توسط جدايه 9 بر روى سطوح باكترى در محيط رسوبى با بزركنمايىهاى مختلف. 100kx .B .5kx .A Fig. 6. SEM images of aggregation of nanocrystals produced by isolate 6 on bacterial cell surfaces in precipitating medium with different magnifications. A. $5 \mathrm{kx}$. B. $100 \mathrm{kx}$.

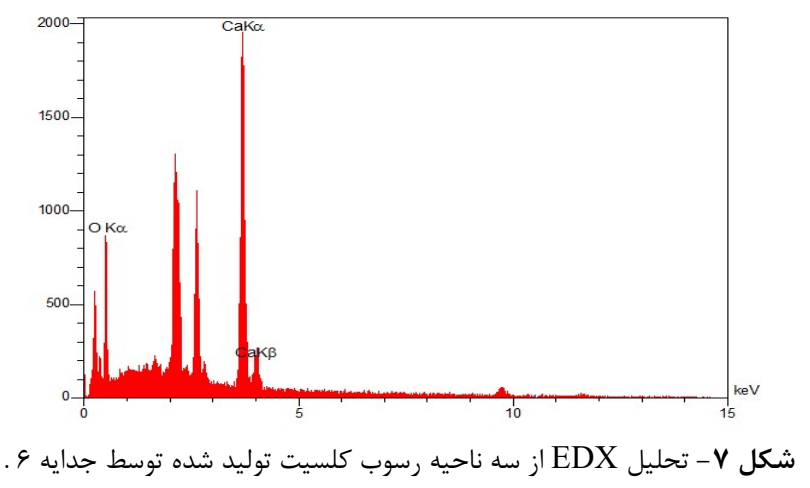

Fig. 7. SEM-EDX analyses of three areas from a calcinated precipitate produced by isolate 6 . 


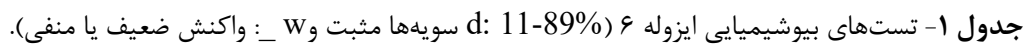

Table 1. Biochemical test results of isolate 6 (d: 11-89\% strain positive and w : weak or negative reaction).

\begin{tabular}{|l|c|c|}
\hline \multicolumn{1}{|c|}{ Characteristics } & $\begin{array}{c}\text { Staphylococcus } \\
\text { xylosus (ATCC29971) }\end{array}$ & Isolate 6 \\
\hline Pigment & $\mathrm{d}$ & - \\
\hline Catalase & + & + \\
\hline Coagulase & - & - \\
\hline Oxidase & + & - \\
\hline Urease & $-\mathrm{W}$ & + \\
\hline Hemolysis & $-{ }^{\mathrm{W}}$ & - \\
\hline $\begin{array}{l}\text { Deoxyribonuclease } \\
\text { (DNase agar) }\end{array}$ & + & - \\
\hline Novobiocin resistance & + & + \\
\hline Growth in the presence of 10 and $15 \%$ NaCl: & + \\
\hline $10 \%$ & d & + \\
\hline $15 \%$ & + & + \\
\hline Aerobic acid production from: & + & + \\
\hline Maltose & + & + \\
\hline Sucrose & + & + \\
\hline Fructose & + & + \\
\hline Lactose & + & + \\
\hline Glucose & + & + \\
\hline Starch & + & + \\
\hline Xylose & + & + \\
\hline Galactose & + & + \\
\hline Mannose & + & + \\
\hline
\end{tabular}

معتدل آزمايش شد كه فقط • م درصد اين سويهها قادر به تشكيل

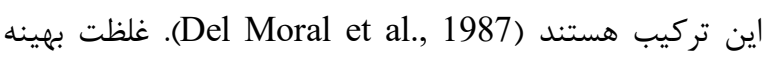
نمك براى رسوب كلسيم كربنات، • ادرصد بود وكلسيت در غلظت • T درصد و در ب/ه درصد نمك مقداركمترى به خود اختصاص داد. باكترى جدا شده در اين بررسى قادر به رشد در در در درد

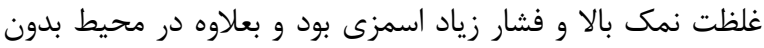
نمك هم رشد نشان داد. مطالعات نشان داد سويهايى از Serratia

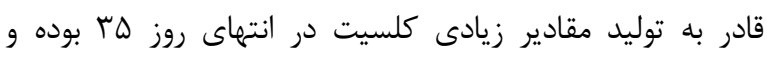
تحليل XRD كريستالهاى كربنات رسوب يافته توسط اين باكترى، كلسيت، واتريت و آراگونيت را نشان داد ( Srivastava et

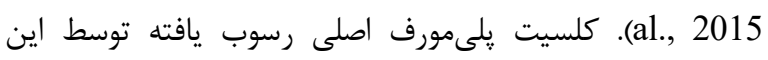
باكترى بود و واتريت ديكر يلىمورف كلسيه كربنات در اين طيف بود. تحليل EDX نشان داد كه رسوب توليد شده به وسيله اين باكترى شامل عناصر Ca, C, O است. مشابه بررسى Srivastava طيف EDX در S. xylosus شامل عناصر Ca, C, O بود كه

$$
\text { حضور كلسيت را تاييد مى كند. }
$$

$$
\text { سياسخزارى }
$$

نويسند اهواز به دليل حمايت مالى اين گيايان نامه تشكر مىنمايند.
مطالعه حاضر نيز مانند مطالعه فوق نشان داد كه برخى از

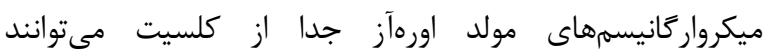
ساختارهاى ديگر كربنات كلسيم و يا حتى كريستالهاى ديگر رائ نيز توليد كنند. S. xylosus در محيط رسوبى فاقد نمك و. •

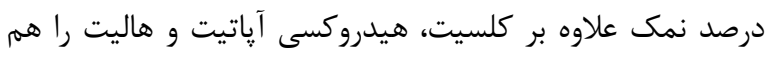
رسوب داد. در محيط رسوبى با ها درصد نمك علاوه بر رسوب

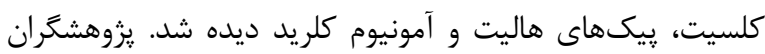
سويه Deleya halophila را كه قادر به تشكيل كلسيه كربنات Ferrer et al., ) تحت همه شرايط بود را مورد آزمايش قرار دادند

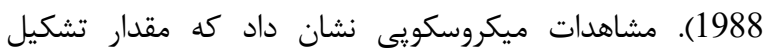

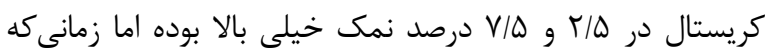
غلظت نمك محيط تا · r درصد افزايش يافت اين مقدار كلسيت

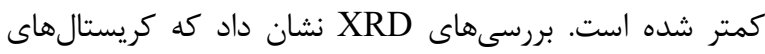
تشكيل شده توسط Dalophila . ha در تمام موارد كلسيت بوده و طى مطالعه با SEM مشخص شد كه تمام كريستالهاى تشكيل شده مورفولوزى مشابه داشتند و كريستالهاى كلسيت تودههاى ير منفذ با منظره كروى شكل دارند. تصاوير ميكروسكوٍ الكترونى موري

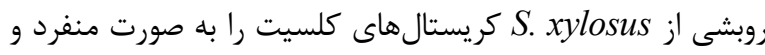
بى شكل يا تودههاى متصل بههم و بىشكل نشان داد. رسوب كلسيت به وسيله زونههاى مختلف باكترىهاى نمكدوست 


\section{REFERENCES}

Arias, D., Valdes, P., Cisternas, L.A. \& Rivas, M. 2015. Isolation and selection of halophilic ureolytic bacteria for biocementation of calcium and magnesium from seawater. Adv. Mat. Res. 1130: 489-492.

Bansal, R., Dhami, N.K., Mukherjee, A. \& Reddy, M.S. 2016. Biocalcification by halophilic bacteria for remediation of concrete structures in marine environment. J. Ind. Microbiol. Biotechnol. 43: 1497-1505.

Brenner, D.J., Krieg, N.R., Staley, J.T. \& Garrity, G.M. 2005. Bergey's manual of systematic bacteriology. Springer-Verlag. New York, pp: 392-420.

Carpa, R., Keul, A., Muntean, V. \& Dobrotă, C. 2014. Characterization of halophilic bacterial communities in Turda salt mine (Romania). Orig. Life. Evol. Biosph. 44: 223-230.

Chahal, N., Rajor, A. \& Siddique, R. 2011. Calcium carbonate precipitation by different bacterial strains. African J. Biotechnol. 10: 8359-8372.

De Muynck, W., De Belie, N. \& Verstraete, W. 2010. Microbial carbonate precipitation in construction materials: a review. Ecol. Eng. 36: 118-136.

Del Moral, A., Roldan, E., Navarro, J., MonteolivaSanchez, M. \& Ramos-Cormenzana, A. 1987. Formation of calcium carbonate crystals by moderately halophilic bacteria. Geomicrobiol. J. 5: 79-87.

Dhami, N.K., Mukherjee, A. \& Reddy, M.S. 2016. Applicability of bacterial biocementation in sustainable construction materials. Asia-Pac. J. Chem. Eng. 11: 795802.

Ferrer, M., Quevedo-Sarmiento, J., Bejar, V., Delgado, R., Ramos-Cormenzana, A. \& Rivadeneyra, M. 1988.
Calcium carbonate formation by Deleya halophila: effect of salt concentration and incubation temperature. Geomicrobiol. J. 6: 49-57.

Hoffman, M.T. \& Arnold, A.E. 2010. Diverse bacteria inhabit living hyphae of phylogenetically diverse fungal endophytes. Appl. Environ. Microbiol. 76: 4063-4075.

Mobley, H.L.T., Méndez, G.L. \& Hazell, S.L. 2001. Helicobacter pylori: Physiology and genetics. - ASM press, Washington.

Oren, A. 2002. Diversity of halophilic microorganisms: environments, phylogeny, physiology, and applications. J. Ind. Microbiol. Biotechnol. 28: 56-63.

Rivadeneyra, M., Ramos-Cormenzana, A., Delgado, G. \& Delgado, R. 1996. Process of carbonate precipitation by Deleya halophila. Curr. Microbiol. 32: 308-313.

Srivastava, S., Bharti, R.K. \& Thakur, I.S. 2015. Characterization of bacteria isolated from palaeoproterozoic metasediments for sequestration of carbon dioxide and formation of calcium carbonate. Environ. Sci. Pollut. Res. 22: 1499-1511.

Stabnikov, V., Jian, C., Ivanov, V. \& Li, Y. 2013. Halotolerant, alkaliphilic urease-producing bacteria from different climate zones and their application for biocementation of sand. World. J. Microbiol. Biotechnol. 29: 1453-1460.

Vahed, S.Z., Forouhandeh, H., Hassanzadeh, S., Klenk, H.P., Hejazi, M.A. \& Hejazi, M.S. 2011. Isolation and characterization of halophilic bacteria from Urmia Lake in Iran. Microbiol. 80: 834-841.

How to cite this article:

Haddadi M. \& Ghezelbash, G.R. 2020. Isolation of halophilic urease producing bacteria and study of their nanocrystal production. Nova Biologica Reperta 7: 37-45. (In Persian).

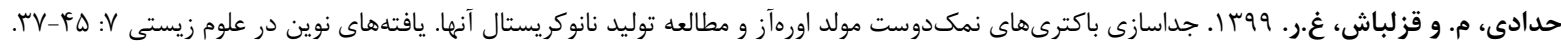

